\title{
FAKTOR-FAKTOR YANG MEMPENGARUHI PENYALAHGUNAAN ASET
}

\author{
Siti Mardiah ${ }^{1}$, Jasman $^{2 *}$ \\ ${ }^{1,2}$ Fakultas Ekonomi dan Bisnis, IKPIA Perbanas, Jakarta \\ *e-mail: sitimardiah27@outlook.com
}

DiPublikasi: 01/07/2021

https://doi.org/10.22225/kr.13.1.2021.14-24

\begin{abstract}
This research aims to examine the influence of pressure, opportunity, rationalization, capability and integrity toward asset misappropriation through fraud star approach in governmental institution. This research used random sampling method and quantitative research design. Primary data is gathered from government employees through questionnaire, whether ministry or non-ministry with 100 respondents. Descriptive statistics, multiple regression model and classical assumption are used to analyze the data. The result of this research showed that rationalization and capability have positive and significant influence on asset misappropriation. Meanwhile, pressure, opportunity and integrity have no influence on asset misappropriation.
\end{abstract}

Keywords: Fraud Star, Asset Misappropriation, Government Institution

\begin{abstract}
Abstrak
Penelitian ini bertujuan untuk menguji pengaruh tekanan, peluang, rasionalisasi, kapabilitas dan integritas terhadap penyalahgunaan aset melalui pendekatan Fraud Star di instansi pemerintah. Penelitian ini menggunakan metode random sampling dan desain penelitian kuantitatif. Data primer dikumpulkan dari pegawai pemerintah melalui kuesioner baik kementerian maupun non kementerian dengan jumlah responden 100 orang. Statistik deskriptif, model regresi berganda dan asumsi klasik digunakan untuk menganalisis data. Hasil penelitian menunjukkan bahwa rasionalisasi dan kapabilitas berpengaruh positif dan signifikan terhadap penyalahgunaan aset. Sedangkan tekanan, peluang dan integritas tidak berpengaruh terhadap penyalahgunaan aset.
\end{abstract}

Kata Kunci : Fraud Star, Penyalahgunaan Aset, Instansi Pemerintah

\section{PENDAHULUAN}

Di era disrupsi yang sedang dihadapi oleh negara-negara di dunia termasuk Indonesia, tentunya akan lebih mengkhawatirkan apa yang akan terjadi di masa depan. Semua ingin mempertahankan, berkembang dan tumbuh, baik sektor publik maupun swasta. Perusahaan dihadapkan pada tiga pilihan besar, keluar dari persaingan, terus mempertahankan posisinya, atau maju sebagai yang terbaik. Untuk memastikan kelangsungan hidupnya, ada beberapa upaya yang harus dilakukan seperti meningkatkan kinerja, produktivitas, efisiensi dan efektivitas dalam mencapai tujuan perusahaan. Dalam melakukan upaya tersebut banyak sekali ancaman yang dihadapi, salah satunya adalah fraud atau kecurangan mulai dari yang kecil, kemudian membesar dan akhirnya akan merugikan perusahaan (Yusar, 2013). Fraud saat ini memang tidak bisa dihindari sehingga dapat ditemukan dalam berbagai kondisi, baik di sektor keuangan maupun non keuangan. Praktik fraud sering terjadi pada perusahaan atau instansi besar maupun kecil dan juga pemerintah.

Dalam laporan survei yang dilakukan oleh The Association of Certified Fraud Examiners (ACFE) Indonesia (2016), jenis penipuan yang paling umum adalah korupsi. Hasil ini menunjukkan perspektif yang berbeda dalam Report to The Nation (RTTN) yang dikeluarkan oleh ACFE (2016). Di RTTN, jenis penipuan yang umum adalah penyalahgunaan aset dengan 83,5 persen kasus dengan kerugian rata-rata $\$ 125.000$. Fraud adalah tindak pidana yang dilakukan untuk mendapatkan keuntungan finansial bagi pelakunya (Sasongko \& Wijayantika, 2019). Ada tiga jenis korupsi di sektor swasta; penyalahgunaan aset, korupsi dan kecurangan laporan keuangan. Untuk sektor publik hanya ada satu jenis fraud yaitu korupsi itu sendiri, sedangkan penyalahgunaan aset dan kecurangan laporan keuangan merupakan 
bagian dari korupsi (Umar dkk., 2019).

Pada tahun 2018, skor Indonesia dalam Corruption Perception Index (CPI) menduduki peringkat 89 dari 180 negara yang diukur tingkat korupsinya, masih tertinggal dari Brunei, Malaysia, dan Singapura dalam masalah pemberantasan korupsi (Transparency International, 2018). Hal ini dibuktikan dengan banyaknya kasus yang melibatkan banyak perusahaan dan organisasi, termasuk instansi swasta atau pemerintah. Seperti pada survei integritas pada 2014 yang dilakukan KPK, seperti dilansir media online www.detik.com (Saputra, 2019), kasus penyalahgunaan aset yang dilakukan Kementerian Agama menempatkan Kementerian Agama pada peringkat terbawah kategori pelayanan publik. Salah satunya kasus korupsi pengadaan dana Al-Quran. Kerugian keuangan negara akibat korupsi pengadaan AlQuran sebesar 27,056 miliar rupiah pada September 2012.

Penyalahgunaan aset juga terjadi di PT Barata Indonesia yang diketahui oleh Kementerian BUMN pada 2011. Dilansir dari www.kompas.com (Rastika, 2011), kasus ini dilakukan oleh Direktur Keuangan, Direktur Pemberdayaan SDM dan Direktur Utama, yang diduga menjual kekayaan negara berupa tanah. Penjualan tersebut diduga bertentangan dengan UU RI Nomor 9 Tahun 2003 tentang BUMN dan Keputusan Menteri Keuangan Nomor 89/KMK.013/1991 tentang Pengalihan Aktiva Tetap BUMN. Korupsi ini dilakukan dengan cara mengurangi nilai jual obyek pajak atas tanah PT Barata Indonesia yang merugikan negara lebih dari 22,690 miliar rupiah.

Kasus korupsi e-KTP berawal dari rencana Kementerian Dalam Negeri RI membuat e-KTP. Sejak 2006, Kementerian Dalam Negeri telah menyiapkan dana sekitar enam triliun rupiah yang digunakan untuk proyek e-KTP dan program Nomor Kependudukan Nasional (NIK) serta dana 258 miliar rupiah untuk biaya pemutakhiran data kependudukan pembuatan e-KTP berbasis NIK tahun 2010 untuk seluruh kabupaten/kota di Indonesia. Indikasi kerugian negara dari kasus ini sebesar 2,3 triliun rupiah (Fadhil, 2018).

Dari beberapa bentuk fraud di atas, terlihat jelas bahwa fraud merupakan masalah yang kompleks dan sulit untuk dihilangkan. Dalam mendeteksi fraud, ada tiga teori yang digunakan untuk menielaskan nenvehabnya Ada teori fraud triangle, fraud diamond dan fraud star. Cressey (1953) memperkenalkan konsep fraud triangle dengan tiga kriteria yang selalu ada dalam tindakan fraud yaitu tekanan, peluang dan rasionalisasi. Crowe Howarth (2011) memperkenalkan teori fraud diamond dengan menambahkan kemampuan pada penelitiannya. Setelah itu Umar (2016) mengedepankan konsep fraud star dengan menambahkan kurangnya integritas pada penelitiannya. Fraud star merupakan penyempurnaan dari dua teori fraud.

Penelitian ini menggunakan pendekatan fraud star dalam fraud terkait dengan penyalahgunaan aset. Fraud star dipilih karena merupakan teori yang paling mutakhir dan lengkap dalam memeriksa laporan keuangan yang mengandung fraud dibandingkan dengan dua teori lainnya. Ini menjelaskan lima elemen penyebab penipuan. Kelima elemen tersebut terdiri dari tekanan, peluang, rasionalisasi, kapabilitas dan kurangnya integritas.

Penyebab pertama yang membuat seseorang melakukan kecurangan adalah tekanan. Dalam penelitian yang dilakukan oleh Manossoh (2017), tekanan berpengaruh positif terhadap fraud yang dilakukan oleh pejabat pemerintah. Sebagian besar tekanan berasal dari lingkungan dan budaya kerja yang tidak menguntungkan yang telah tertanam di dalam organisasi. Hal tersebut dapat memberikan kecenderungan seseorang melakukan fraud. Sebaliknya, hasil penelitian yang dilakukan oleh Faisal (2013) menyatakan bahwa tekanan tidak berpengaruh terhadap fraud. Memang, pegawai akan cenderung melakukan fraud ketika merasa tertekan, baik itu tekanan yang berasal dari diri sendiri seperti kesulitan keuangan atau faktor lain yang bisa berasal dari organisasi seperti budaya organisasi dan lingkungan kerja. Namun seberapa besar pun tekanan yang dirasakan, kecenderungan melakukan fraud masih bergantung pada individunya, apakah ia akan melakukan fraud atau tidak (Faisal, 2013).

Faktor lain yang mempengaruhi terjadinya fraud adalah peluang. Peluang untuk melakukan kecurangan dapat terjadi ketika pengendalian internal yang dilakukan oleh organisasi kurang baik atau tidak efektif. Wilopo (2010) dalam Pristiyanti (2012) juga mengatakan bahwa semakin baik pengendalian internal maka semakin kecil kemungkinan terjadinya fraud di sektor 
pemerintahan. Hasil penelitian yang dilakukan oleh Zulkarnain (2013) menunjukkan bahwa pengendalian internal berpengaruh negatif terhadap kecenderungan melakukan fraud. Pengendalian internal yang efektif akan terintegrasi dengan perilaku anggota organisasi sehingga akan menekan perilaku tidak etis yang mungkin terjadi.

Rasionalisasi sering digunakan oleh pelaku untuk memperbaiki fraud yang dilakukannya. Sarpta (2018) mengatakan bahwa rasionalisasi memiliki pengaruh yang signifikan terhadap terjadinya kecurangan. Rasionalisasi digunakan sebagai pembenaran atas kesalahan atau fraud yang dilakukan oleh seseorang. Sebaliknya, penelitian yang dilakukan oleh Faradiza (2019) menunjukkan bahwa rasionalisasi tidak berpengaruh terhadap fraud. Albrecht dkk. (2011) menyatakan bahwa rasionalisasi yang sering terjadi ketika melakukan fraud antara lain adalah aset tersebut sebenarnya milik saya, saya hanya meminjam dan akan melunasinya, tidak ada pihak yang dirugikan, hal ini dilakukan untuk sesuatu yang mendesak, akan diselesaikan setelah masalah keuangan sudah selesai dan saya bersedia mengorbankan reputasi dan integritas saya selama itu meningkatkan standar hidup saya.

Cara yang sering dilakukan dalam penyalahgunaan aset adalah dengan memanfaatkan kekuasaan yang dimiliki. Kemampuan kemudian menjadi faktor keempat yang mempengaruhi

\section{TINJAUAN PUSTAKA}

\section{Teori Keagenan}

Jensen dan Meckling (1976) menyatakan bahwa hubungan keagenan muncul karena kontrak antara prinsipal dan agen dengan mendelegasikań... beberapa otoritas pengambilan keputusan kepada agen. Sesuai dengan kesepakatan dapat diasumsikan bahwa beberapa keputusan akan memberikan kewenangan kepada agen. Teori keagenan mengasumsikan bahwa setiap individu hanya dimotivasi oleh kepentingannya sendiri sehingga menimbulkan konflik kepentingan antara principal dan agen. Dalam pelaksanaannya, pegawai (agen) memiliki tanggung jawab untuk dapat meningkatkan kinerja perusahaan (prinsipal), namun pegawai juga berkepentingan untuk memaksimalkan kesejahteraan pribadinya.

Fraud Dalam Bentuk Penyalahgunaan Aset seseorang untuk melakukan fraud. Dalam kondisi tertentu sistem dan sumber daya yang buruk dapat membuat suatu lembaga berjalan dengan buruk dan begitu pula sebaliknya. Pada kondisi lain, pejabat yang memiliki kekuasaan dan melakukan penyalahgunaan kekuasaan juga akan membuat kinerja lembaga menjadi buruk sehingga akan meningkatkan fraud (Manossoh, 2017). Sedangkan menurut Yudistira dkk. (2017), otoritas tidak berpengaruh pada fraud. Artinya, kewenangan yang dimiliki oleh seseorang telah dilaksanakan secara bijaksana untuk mencapai tujuan organisasi atau lembaga itu sendiri sehingga tidak timbul tindakan fraud atau penyalahgunaan asset akibat penyalahgunaan wewenang.

Dalam teori fraud star, faktor terakhir yang mempengaruhi seseorang melakukan fraud adalah kurangnya integritas. Dalam penelitiannya, Umar (2016) mengatakan bahwa seseorang akan melakukan kecurangan jika kehilangan integritasnya. Jika seseorang kehilangan integritasnya, maka dia akan kehilangan segalanya. Seseorang dengan integritas tinggi tidak akan mudah terjebak oleh situasi, depresi, atau imingiming yang ditawarkan dengan melakukan fraud. Sebaliknya, Fitriani (2014) menunjukkan bahwa integritas tidak berpengaruh terhadap fraud karena integritas merupakan variabel yang tidak dapat diukur secara akurat.

Kerangka Kerja Praktik Profesional Internasional IIA (IIA, 2016) mendefinisikan fraud sebagai berikut.

any illegal act characterized by deceit, concealment, or violation of trust. These acts are not dependent upon the threat of violence or physical force. Frauds are perpetrated by parties and organizations to obtain money, property, or services; to avoid payment or loss of services; or to secure personal or business advantage".

Sementara itu, Black's Law Dictionary (1990) mendefinisikan fraud sebagai kumpulan semua cara yang beraneka ragam yang dapat dibuat oleh kecerdikan manusia, dan yang digunakan oleh satu individu untuk mendapatkan keuntungan dari yang lain dengan penindasan kebenaran, dan mencakup 
semua kegiatan, tipuan, kelicikan, atau menyembunyikan, dan cara tidak adil apa pun yang digunakan orang lain untuk menipu.

Dari beberapa definisi fraud di atas, dapat disimpulkan bahwa fraud merupakan tindakan yang disengaja antara lain berbohong, mencuri, memanipulasi, dan menggelapkan (mengubah aset perusahaan secara tidak benar untuk kepentingan sendiri). Fraud sendiri umumnya merupakan tindakan ilegal yang dilakukan oleh seseorang dari dalam maupun luar organisasi untuk mendapatkan keuntungan pribadi atau kelompok yang secara langsung merugikan pihak lain.

Association of Certified Fraud Examiners (ACFE, 2016) mengklasifikasikan fraud ke dalam tiga kategori yang dikenal dengan "Fraud Tree". Ada kecurangan laporan keuangan, penyalahgunaan aset, dan korupsi. Kecurangan laporan keuangan dapat diartikan sebagai kecurangan yang dilakukan oleh manajemen berupa salah saji material atas laporan keuangan yang merugikan investor dan kreditor. Penipuan ini bisa berupa penipuan finansial atau non-finansial. Penyalahgunaan aset dapat diklasifikasikan sebagai penipuan tunai dan kecurangan pada inventaris dan aset lainnya, serta pencairan dana yang curang. Penyalahgunaan aset atau pengambilan aset secara ilegal dalam aktivitas sehari-hari disebut mencuri. Namun secara hukum, pengambilan aset secara ilegal oleh seseorang yang diberi wewenang untuk mengelola atau menangani aset tersebut, disebut penggelapan. Sedangkan korupsi memiliki beberapa arti. Menurut ACFE, korupsi dibagi menjadi konflik kepentingan, suap, gratifikasi ilegal, dan pemerasan ekonomi. Dalam pasal yang tertuang dalam UU 20 Tahun 2002 yang mengacu pada UU 31 Tahun 1999, korupsi terjadi jika memenuhi tiga kriteria: (1) melawan hukum, (2) memperkaya diri sendiri atau orang lain atau korporasi, dan (3) merugikan keunagan negara atau ekonomi negara.

\section{Tekanan}

Fraud dapat dilakukan untuk kepentingan individu atau untuk organisasi itu sendiri. Fraud yang dilakukan pegawai, seperti penggelapan atau penyalahgunaan aset di suatu perusahaan biasanya hanya menguntungkan individunya saja. Tekanan itu sendiri dapat berdampak positif, tekanan dapat membuat kita meningkatkan perhatian dalam melakukan tindakan ataw meninokatkan dava ingat dan kemampuan untuk mengingat. Dengan kata lain, tekanan dapat meningkatkan kinerja. Namun di sisi lain, tekanan bisa menjadi penyebab seseorang melakukan fraud. Jadi, ini menjadi salah satu elemen fraud star.

Albrecht dkk. (2012) membagi tekanan menjadi 4 kategori yaitu tekanan keuangan, tekanan karena perilaku, tekanan terkait pegawaian, dan tekanan lainnya. Kebanyakan fraud melibatkan tekanan keuangan dan tekanan karena perilaku. Sedangkan Vona (2008) berpendapat bahwa tekanan dapat dibagi menjadi tekanan pribadi, tekanan perusahaan atau tekanan eksternal.

\section{Peluang}

Menurut Albrecht dkk. (2012) sedikitnya terdapat 6 faktor yang meningkatkan kemungkinan terjadinya fraud dalam suatu organisasi, yaitu pengendalian internal yang lemah, ketidakdisiplinan, kurangnya komunikasi dan informasi, kurangnya jejak audit, dan sikap apatis. Pengendalian internal yang meliputi lingkungan pengendalian, sistem akuntansi, dan variasi kegiatan pengendalian bekerja sama untuk mengurangi peluang pegawai melakukan kecurangan. Peluang terjadinya fraud juga dapat terjadi jika manajemen tidak mampu memberikan penilaian terhadap kualitas kinerja pegawainya. Fraud juga sering terjadi karena korban tidak memiliki akses informasi yang dimiliki oleh pelaku dan sikap apatis. Oleh karena itu, untuk menghindari fraud seseorang harus meminta pengungkapan penuh. Orang yang apatis dan orang yang tidak memiliki kapabilitas seringkali menjadi korban fraud karena pelaku mengetahui bahwa orang tersebut mungkin tidak memiliki kapasitas atau pengetahuan untuk mendeteksi bahwa pelaku melakukan perbuatan melawan hukum.

\section{Rasionalisai}

Faktor ketiga yang menyebabkan fraud adalah rasionalisasi. Rasionalisasi dapat diartikan sebagai tindakan atau semacam pembenaran oleh orangorang yang merasa terjebak dalam situasi yang buruk (Albrecht, 2012). Pelaku akan mencari alasan untuk membenarkan kejahatan tersebut bagi dirinya sendiri agar perbuatan yang dilakukannya dapat diterima oleh masyarakat. Rasionalisasi yang sering digunakan adalah (1) organisasi berhutang pada saya, (2) saya hanya meminjam uang, akan saya kembalikan nanti, (3) tidak ada pihak yang 
dirugikan, (4) saya memiliki hak yang lebih besar, (5) ini untuk tujuan yang baik, (6) semua mendapatkan kekayaan, mengapa saya tidak, (7) perusahaan mengizinkan ini, (8) mereka tidak memperlakukan saya dengan hormat, jadi saya ingin mendapatkannya sendiri. Kita dapat menarik kesimpulan bahwa alasan yang digunakan untuk menutupi fraud adalah hal yang umum bagi para pelakunya. Jika dilakukan secara terus menerus maka rasionalisasi dapat menjadi penyebab utama terjadinya fraud di perusahaan. Hal ini harus menjadi perhatian perusahaan agar kebiasaan rasionalisasi para pelaku fraud tidak terus berkembang.

\section{Kapabilitas}

Kapabilitas artinya seberapa besar kekuatan dan kapasitas seseorang untuk melakukan fraud di dalam perusahaan (Apriliana dan Agustina, 2017). Kapabilitas adalah pengembangan dari elemen peluang. Ini adalah kemampuan pegawai untuk mengesampingkan pengendalian internal dengan mengembangkan strategi dan mengendalikan situasi sosial demi keuntungan mereka. Misalnya, seorang pegawai yang memiliki kemampuan untuk mengetahui aset perusahaan menjualnya kepada pihak lain atau mengambilnya untuk keuntungannya sendiri. Wolfe dan Hermanson (2004) mendefinisikan unsur kapabilitas dalam tindakan pelaku fraud sebagai posisi/otoritas, kecerdasan, ego/keyakinan, paksaan, penipuan dan ketahanan stres.

\section{Integritas}

Integritas adalah kualitas, ciri atau kondisi dimana seseorang menunjukkan kualitas, kerja keras dan kompetensi yang memadai dalam segala hal yang dilakukannya (Siahaan dkk., 2019). Seseorang yang berintegritas tidak pernah mengkhawatirkan konsekuensi dari tindakan atau sikapnya meskipun hal itu tidak disukai oleh orangorang di sekitarnya. Mereka yang berintegritas biasanya jauh dari niat kriminal karena semua yang mereka lakukan berdasarkan kebenaran dan etika (Umar, 2016). Mereka akan terus memegang teguh prinsip kebaikan dalam kondisi apapun dan dimanapun.

Menurut Bakri dan Said (2017) dalam Siahaan dkk. (2019) integritas dibagi menjadi dua elemen yaitu faktor internal dan faktor eksternal. Faktor internal adalah kepribadian seseorang. Itu bisa menjadi prinsip, nilai, komitmen, atau keyakinan yang dianut oleh seseorang. Perilaku juga merupakan faktor internal yang berperan penting dalam pembentukan integritas, apakah seseorang mampu berperilaku baik dalam kondisi apapun atau mampu terguncang oleh kondisi yang ada di luar dirinya. Sedangkan faktor eksternal meliputi reward dan punishment yang diterapkan lingkungan terhadap perilaku atau kinerja seseorang.

\section{Hipotesis}

Sebagaimana yang telah dijelaskan melalui teori keagenan, setiap individu hanya dimotivasi oleh kepentingannya sendiri sehingga menimbulkan benturan kepentingan antara prinsipal dan agen. Dalam pelaksanaannya, pegawai (agen) memiliki tanggung jawab untuk dapat meningkatkan kinerja perusahaan (prinsipal), namun pegawai juga berkepentingan untuk memaksimalkan kesejahteraan pribadinya (Fitri dan Nadirsyah, 2019). Tekanan yang dirasakan pegawai bisa datang dari mana saja, baik internal maupun eksternal (Manossoh, 2017). Tekanan internal seringkali dirasakan oleh pegawai yang merasa bahwa gajinya tidak sesuai dengan pegawaiannya. Selain itu, tekanan eksternal seperti besarnya hutang juga dapat mendorong seseorang melakukan fraud. Lingkungan kerja juga sering memberikan tekanan tinggi pada pelaku dalam melakukan fraud, terutama jika perusahaan memiliki budaya etis yang kurang baik (Faisal, 2013).

H1 : Tekanan memiliki pengaruh positif dan signifikan terhadap penyalahgunaan aset

Fraud bisa terjadi saat ada peluang bagi pegawai. Salah satu kondisi yang dapat menciptakan peluang untuk melakukan kecurangan adalah pengendalian internal yang lemah. Wilopo dalam Pristiyanti (2012) mengatakan bahwa semakin baik pengendalian intern maka semakin kecil kemungkinan tingkat fraud di sektor pemerintahan. Hasil penelitian yang dilakukan oleh Zulkarnain (2013) menunjukkan bahwa pengendalian internal berpengaruh negatif terhadap kecenderungan melakukan fraud. Pengendalian internal yang efektif akan terintegrasi dengan perilaku anggota organisasi sehingga akan menekan perilaku tidak etis yang mungkin terjadi.

Faktor lain yang dapat menciptakan peluang adalah kurangnya akses komunikasi dan informasi 
dalam organisasi, manajemen yang tidak mampu membujuk pelaku fraud, dan sikap apatis yang ditunjukkan oleh manajemen dan pegawai tentang kecurangan kecil dan kurangnya jejak audit (Fitri \& Nadirsyah, 2019). Ketika semua kondisi tersebut terjadi, maka fraud berupa penyalahgunaan asset akan semakin banyak dilakukan oleh pegawai. Apalagi jika fraud tidak dapat dideteksi selama periode audit, kemungkinan besar bukti atau jejak audit tersebut akan segera dihapus setelah auditor selesai masa auditnya (Umar, 2016).

$\mathrm{H} 2$ : Peluang berpengaruh positif dan signifikan terhadap penyalahgunaan asset

Rasionalisasi sering digunakan oleh para pelaku dan dipersiapkan bahkan sebelum melakukan fraud (Sarpta, 2018). Rasionalisasi sudah menjadi hal yang lumrah bagi sebagian orang karena penyalahgunaan aset seringkali hanya disebut sebagai fraud kecil-kecilan yang mungkin tidak terdeteksi oleh perusahaan (Fitri dan Nadirsyah, 2019). Misalnya, pengambilalihan aset perusahaan berupa peralatan kantor atau fasilitas kantor yang sering digunakan pegawai dalam aktivitas sehari-hari sudah sangat umum terjadi. Pegawai merasa bahwa fasilitas dan aset diberikan sepenuhnya kepada mereka sehingga tidak ada perasaan bahwa aset atau fasilitas tersebut harus selalu digunakan untuk kebutuhan perusahaan tetapi dapat juga digunakan untuk kebutuhan pribadi masing-masing pegawai.

Selain itu, kerugian yang timbul akibat penyalahgunaan aset merupakan yang terkecil jika dibandingkan dengan jenis fraud lainnya (ACFE, 2016). Hal ini membuat manajemen kerap membiarkan penyalahgunaan aset terjadi begitu saja tanpa sanksi yang jelas padahal mereka tahu telah terjadi penyalahgunaan aset.

H3: Rasionalisasi berpengaruh positif dan signifikan terhadap penyalahgunaan aset

\section{METODE PENELITIAN}

Variabel terikat dalam penelitian ini adalah penyalahgunaan aset (Y). Sedangkan variabel bebas dalam penelitian ini terdiri dari tekanan (X1), peluang (X2), rasionalisasi (X3), kapabilitas (X4) dan kurangnya integritas (X5).

Populasi yang digunakan dalam penelitian ini adalah pegawai yang bekerja pada instansi pemerintah baik kementerian maupun non
Kapabilitas seseorang merupakan faktor kualitatif yang menurut Wolfe dan Hermanson (2004) merupakan pelengkap model fraud triangle Cressey. Kapabilitas berarti kekuatan dan kapasitas seseorang untuk melakukan fraud di lingkungan perusahaan. Pegawai yang memiliki kekuasaan dan melakukan penyalahgunaan kekuasaan akan membuat kinerja institusi berjalan buruk, sehingga akan meningkatkan fraud (Manossoh, 2017). Tidak hanya karena pegawai memiliki kapabilitas atau kemampuan untuk melakukan fraud, kewenangannya juga meningkatkan kemungkinan terjadinya fraud dalam bentuk penyalahgunaan aset. Semakin luas kewenangan yang dimiliki seseorang maka semakin besar kemungkinan ia akan melakukan penyalahgunaan aset dalam organisasi.

H4 : Rasionalisasi berpengaruh positif dan signifikan terhadap penyalahgunaan aset

Dalam teori fraud star, faktor terakhir yang mempengaruhi seseorang melakukan fraud adalah kurangnya integritas. Dalam penelitiannya, Umar (2016) mengatakan bahwa seseorang akan melakukan kecurangan jika kehilangan integritasnya. Jika seseorang kehilangan integritasnya, maka dia akan kehilangan segalanya. Seseorang dengan integritas tinggi tidak akan mudah terjebak oleh situasi, depresi, atau imingiming yang ditawarkan dengan melakukan fraud. Salah satu tugas pegawai pemerintah adalah mengabdi kepada masyarakat. Integritas yang tinggi sangat penting bagi pegawai pemerintah (Siahaan dkk., 2019). Jika telah menyalahgunakan aset, berarti tidak layak dipercaya oleh masyarakat karena telah mengkhianati masyarakat (Umar, 2016).

H5 : Integritas memiliki pengaruh negatif dan signifikan terhadap penyalahgunaan aset

kementerian. Sampel dalam penelitian ini adalah pegawai yang bekerja pada instansi pemerintah baik kementerian maupun non kementerian di wilayah Jakarta Selatan dan Jakarta Pusat. Daerahdaerah tersebut dipilih karena banyak instansi pemerintah yang berada di daerah tersebut. Dengan demikian, peneliti dapat memperoleh data dengan mudah. Teknik pengambilan sampel yang 
digunakan dalam penelitian ini adalah simple random sampling. Artinya setiap elemen dipilih secara acak dari setiap elemen lainnya (Amirullah, 2015). Teknik simple random sampling digunakan karena ada batasan. Responden tidak tertarik untuk mengisi kuesioner jika harus menyebutkan instansinya karena alasan kerahasiaan.

Data yang digunakan dalam penelitian ini adalah data primer yang diperoleh langsung dan tanpa perantara dari responden melalui kuesioner yang disebarkan kepada responden dan diisi oleh responden. Kuesioner dibagikan kepada responden melalui platform online menggunakan formulir Google. Indikator dan instrumen variabel bebas kuesioner yang disebarkan dalam penelitian ini

\section{HASIL DAN PEMBAHASAN}

\section{Statistik Deskriptif}

Objek penelitian yang digunakan dalam penelitian ini adalah instansi pemerintah baik itu kementerian maupun non kementerian. Peneliti mendapatkan sebanyak 100 responden. Deskripsi dikembangkan oleh Siahaan dkk. (2019).

Analisis statistik deskriptif adalah analisis yang digunakan untuk menganalisis data dalam penelitian ini. Teknik ini mendeskripsikan data yang telah dikumpulkan apa adanya tanpa maksud untuk membuat kesimpulan yang berlaku secara umum atau generalisasi (Muhson, 2015). Menurut Sugiyono (2017), statistik deskriptif merupakan analisis yang memberikan gambaran suatu data agar informasi lebih jelas dan mudah dipahami dilihat dari mean, median, modus, deviasi standar, nilai maksimum, dan nilai minimum. Perangkat lunak yang digunakan untuk teknik analisis ini adalah SPSS versi 24.

variabel penelitian ini akan menampilkan tabel yang menunjukkan nilai rata-rata dan standar deviasi jawaban tiap variabel hasil pengisian kuesioner oleh responden.

Tabel 1

Statistik Deskriptif

\begin{tabular}{lcc}
\hline Variabel & Mean & Std. Deviasi \\
\hline Tekanan & 25,74 & 4,017 \\
Kesempatan & 19,20 & 3,879 \\
Rasionalisasi & 11,51 & 4,160 \\
Kapabilitas & 20,97 & 3,770 \\
Integritas & 21,83 & 4,283 \\
Penyalahgunaan Aset & 16,00 & 5,107 \\
\hline
\end{tabular}

Nilai rata-rata variable tekanan berada di sekitar 25,74 dengan standar deviasi 4,017. Hasilnya dapat dikatakan bahwa tekanan di instansi pemerintah cenderung memiliki tekanan (rata-rata) yang cukup bagi para pegawai untuk melakukan penyalahgunaan aset.

Variabel peluang memiliki nilai rata-rata 19,20 dan standar deviasi 3,879. Sehingga pegawai di instansi pemerintah cenderung memiliki peluang yang cukup untuk melakukan penyalahgunaan aset.

Sedangkan rasionalisasi memiliki nilai ratarata yang rendah yaitu 11,51 dengan standar deviasi 4,160. Artinya di instansi pemerintah, pegawai melakukan sedikit rasionalisasi ketika terjadi penyalahgunaan aset. dengan standar deviasi 3,770. Hasilnya dapat dikatakan bahwa pegawai di instansi pemerintah memiliki kemampuan yang cukup untuk melakukan penyalahgunaan aset.

Variabel integritas memiliki nilai rata-rata 21,83 dengan standar deviasi 4,283. Sehingga dapat dikatakan bahwa pada instansi pemerintah pegawai memiliki integritas atau tidak terdapat kekurangan integritas yang dapat mendorong seseorang untuk melakukan penyalahgunaan aset.

Dan untuk variabel penyalahgunaan aset terlihat bahwa nilai standar deviasi 6,107 lebih kecil dari nilai mean, nilai sampel berada di sekitar nilai rata-rata 16,00 . Sehingga, penyalahgunaan aset terkadang terjadi di instansi pemerintah. 
Uji validitas instrumen yang digunakan dalam penelitian ini menggunakan uji pearson product moment dengan kaidah pengambilan keputusan jika r-hitung > r-tabel maka dapat disimpulkan bahwa instrumen angket layak digunakan dalam pengumpulan data penelitian. Nilai r-tabel untuk total data 100 pada nilai signifikansi 5\% adalah 0,195 (Sugiyono, 2009: 524). Semua item angket dalam penelitian ini telah lolos uji validitas. Uji reliabilitas dilakukan dengan metode internal consistency. Dalam penelitian ini digunakan composite reliability dan koefisien Cronbach's Alpha. Suatu konstruk dikatakan reliabel jika nilai composite reliability dan cronbach alpha berada di atas 0,60 (Sugiyono, 2009). Setiap variabel dalam penelitian ini memiliki nilai lebih dari 0,60 yang berarti setiap konstruk memiliki reliabilitas yang baik.

\section{Hasil Uji Hipotesis}

Uji normalitas data dapat dilakukan dengan mengamati plot probabilitas normal. Jika residual berasal dari sebaran normal, maka nilai sebaran akan berada disekitar garis lurus yang merupakan garis dari sebaran normal (Sarwoko, 2005 dalam Wasef, 2010). Variabel dalam penelitian ini telah lolos uji normalitas. Selain itu, variabel independen atau independen yang digunakan dalam penelitian ini tidak menunjukkan gejala multikolinieritas karena nilai toleransinya $>0,10$ dan nilai VIF $<10$. Uji heteroskedastisitas dilakukan untuk melihat grafik plot antara nilai prediksi variabel dependen (ZPRED) dan residualnya (SRESID) juga menunjukkan bahwa tidak terdapat heteroskedastisitas yang teridentifikasi dalam model regresi yang digunakan. Titik-titik tersebut tidak membentuk pola tertentu atau titik-titik yang tersebar. sehingga tidak terjadi heteroskedastisitas pada model regresi yang digunakan. Dalam penelitian ini pengujian autokorelasi yang digunakan adalah Metode Durbin Watson (DW). Nilai DW pada penelitian ini adalah 1,418. Sehingga dapat disimpulkan bahwa tidak terjadi autokorelasi karena nilai DW berada diantara -2 dan 2.

Hasil pengujian hipotesis disajikan pada tabel 2 di bawah ini.

\section{Tabel 2}

Hasil Uji Hipotesis

\begin{tabular}{lcc}
\hline Variabel & Koefisien & Signifikansi \\
\hline Tekanan & 0,193 & 0,123 \\
Peluang & 0,056 & 0,651 \\
Rasionalisasi & 0,408 & 0,002 \\
Kapabilitas & 0,386 & 0,002 \\
Integritas & 0,179 & 0,146 \\
\hline
\end{tabular}

Dependent Variable : Penyalahgunaan Aset

Tabel 2 menunjukkan bahwa sig. value tekanan 0,123. Nilai tersebut lebih besar dari 0,05, sehingga H0 ditolak. Artinya tekanan tidak berpengaruh terhadap penyalahgunaan aset. Hasil ini sejalan dengan penelitian yang dilakukan oleh Faisal (2013) dan Didi \& Kusuma (2018) yang menyatakan bahwa tekanan tidak berpengaruh terhadap fraud yang dilakukan oleh pegawai. Ini bisa disebabkan oleh beberapa faktor. Tugas pegawai pemerintah adalah melayani masyarakat. Mereka harus bekerja secara sukarela untuk membantu meningkatkan kesejahteraan masyarakat. Meski banyak yang menganggap bahwa gaji menjadi pegawai pemerintah itu kecil atau tidak sesuai, namun bukan tekanan yang bisa membuat mereka melakukan fraud yang akan merugikan masyarakat dan instansinya.
Seperti yang disajikan pada tabel 2, sig. value peluang adalah 0,651. Nilai tersebut lebih besar dari 0,05 , sehingga H0 ditolak. Artinya peluang tidak berpengaruh terhadap penyalahgunaan aset. Hasil ini sejalan dengan penelitian yang dilakukan oleh Wicaksana dkk. (2019) dan Fitri \& Nadirsyah (2019) yang menyatakan bahwa peluang tidak berpengaruh terhadap fraud yang dilakukan oleh pegawai. Hal ini dapat disebabkan oleh sistem pengendalian yang diterapkan di suatu organisasi sudah efektif sehingga menyulitkan pelakunya. Selain itu, semakin baik sistem pengendalian internal maka kemungkinan terjadinya fraud akan semakin jarang terjadi. Hal ini mengakibatkan sedikitnya peluang yang tersedia bagi pegawai untuk melakukan penyalahgunaan aset. Selain itu, dengan adanya prosedur dan regulasi yang ketat di 
lembaga pemerintahan, tidak semua orang dapat terlibat dalam kegiatan pemerintahan kecuali mereka yang memang memiliki tanggung jawab.

Tabel 2 menunjukkan bahwa sig. value rasionalisasi adalah 0,002 . Nilai tersebut kurang dari 0,05 , sehingga $\mathrm{H} 0$ diterima. Artinya rasionalisasi berpengaruh positif dan signifikan terhadap penyalahgunaan aset. Hasil ini sejalan dengan penelitian yang dilakukan oleh Siahaan dkk. (2019), Irphani (2017), Faradiza (2019), dan Manossoh (2017) yang menyatakan bahwa rasionalisasi berpengaruh terhadap fraud yang dilakukan oleh pegawai. Rasionalisasi sudah menjadi hal yang lumrah bagi sebagian orang karena penyalahgunaan aset sering disebut sebagai fraud kecil yang mungkin tidak terdeteksi oleh perusahaan. Misalnya, sangat umum pegawai pemerintah menggunakan aset dan fasilitas untuk kepentingannya sendiri. Pegawai merasa bahwa fasilitas dan aset diberikan sepenuhnya kepada mereka sehingga tidak ada perasaan bahwa aset atau fasilitas tersebut harus selalu digunakan untuk kebutuhan perusahaan tetapi dapat juga digunakan untuk kebutuhan pribadi masing-masing pegawai.

Variabel kapabilitas seperti yang disajikan pada tabel 2 menunjukkan bahwa sig. value kapabilitas yaitu 0,002 . Nilai tersebut kurang dari 0,05, sehingga H0 diterima. Artinya kapabilitas berpengaruh positif dan signifikan terhadap penyalahgunaan aset. Hasil ini sejalan dengan penelitian yang dilakukan oleh Siahaan dkk. (2019), Irphani (2017), dan Fitri \& Nadirsyah (2019) yang menyatakan bahwa rasionalisasi berpengaruh terhadap fraud. Pegawai yang memiliki kekuasaan dan melakukan penyalahgunaan kekuasaan akan membuat kinerja institusi berjalan buruk, sehingga akan meningkatkan fraud (Manossoh, 2017). Tidak hanya karena pegawai memiliki kapabilitas atau kemampuan untuk melakukan fraud, kewenangannya juga meningkatkan kemungkinan terjadinya fraud dalam bentuk penyalahgunaan aset. Semakin luas kewenangan yang dimiliki seseorang, maka semakin besar kemungkinan ia akan melakukan penyalahgunaan aset dalam organisasi. Umumnya masyarakat yang memiliki kapabilitas juga pandai memanfaatkan kelemahan pengendalian internal perusahaan untuk mencari celah untuk melakukan fraud.

Tabel 2 juga menunjukkan bahwa sig. value integritas adalah 0,146. Nilai tersebut lebih besar dari 0,05 , sehingga H0 ditolak. Artinya integritas tidak berpengaruh terhadap penyalahgunaan aset. Hasil ini sejalan dengan penelitian yang dilakukan oleh Wicaksana dkk. (2019) dan Fitri \& Nadirsyah (2019) yang menyatakan bahwa integritas tidak berpengaruh terhadap fraud. Hasil regresi ini menunjukkan bahwa integritas bukanlah penyebab utama terjadinya fraud berupa penyalahgunaan aset di instansi pemerintah. Selain integritas, rasionalisasi dan kapabilitas seseorang untuk melakukan fraud lebih kuat untuk mendorong seseorang melakukan fraud. Kemungkinan lainnya adalah indikator yang digunakan untuk mengukur integritas masih belum sesuai dengan yang seharusnya digunakan. Skousen dkk. (2009) dalam Fitriany (2014) mengatakan bahwa integritas merupakan salah satu penyebab fraud yang paling sulit diukur sehingga memungkinkan terjadinya ketidakakuratan dalam mengukur tingkat integritas

\section{KESIMPULAN DAN SARAN Kesimpulan}

Variabel tekanan tidak berpengaruh terhadap penyalahgunaan aset. Tugas pegawai pemerintah adalah melayani masyarakat. Mereka harus bekerja secara sukarela untuk membantu meningkatkan kesejahteraan masyarakat. Meski banyak yang menilai bahwa gaji menjadi pegawai pemerintah kecil atau tidak sesuai, namun bukan tekanan lah yang dapat menyebabkan mereka melakukan kecurangan yang akan merugikan masyarakat dan institusi mereka.

Variabel peluang tidak berpengaruh terhadap penyalahgunaan aset. Hal ini dapat disebabkan oleh sistem pengendalian yang diterapkan dalam suatu organisasi yang telah efektif sehingga menyulitkan pelakunya. Selain itu, dengan adanya prosedur dan peraturan yang ketat di lembaga pemerintah, tidak semua orang dapat terlibat dalam kegiatan pemerintahan kecuali yang memang memiliki tanggung jawab.

Variabel rasionalisasi berpengaruh positif dan signifikan terhadap penyalahgunaan aset. Rasionalisasi_sudah meniadi_hal yang lumrah hagi 
sebagian orang karena penyalahgunaan aset sering disebut sebagai penipuan kecil yang mungkin tidak terdeteksi oleh perusahaan. Pegawai merasa bahwa fasilitas dan aset diberikan sepenuhnya kepada mereka sehingga tidak ada perasaan bahwa aset atau fasilitas tersebut harus selalu digunakan untuk kebutuhan perusahaan tetapi dapat juga digunakan untuk kebutuhan pribadi masing-masing pegawai. Variabel kapabilitas berpengaruh signifikan positif dan signifikan terhadap penyalahgunaan aset. Pegawai yang memiliki kekuasaan dan melakukan penyalahgunaan kekuasaannya juga akan membuat kinerja institusi berjalan buruk, sehingga akan meningkatkan kecurangan. Tidak hanya karena pegawai memiliki kapabilitas atau kemampuan untuk melakukan fraud, kewenangannya juga meningkatkan kemungkinan terjadinya fraud dalam bentuk penyalahgunaan aset. Semakin luas kewenangan yang dimiliki seseorang maka semakin besar kemungkinan ia akan melakukan penyalahgunaan aset dalam organisasi.

Variabel integritas tidak berpengaruh terhadap penyalahgunaan aset. Hal ini menunjukkan bahwa integritas bukanlah penyebab utama terjadinya fraud berupa penyalahgunaan aset di instansi pemerintah. Kemungkinan lainnya adalah indikator yang digunakan untuk mengukur integritas masih belum sesuai dengan yang harus digunakan karena integritas merupakan salah satu faktor penyebab

\section{DAFTAR PUSTAKA}

Albrecht, W. S., C. O. Albrecht, C. C. Albrecht, dan M. F. Zimbelman. 2012. Fraud Examination. 4th Edition. South-Western: Cengange Learning

Amirullah. (2015). Populasi dan Sampel (Pemahaman, Jenis dan Teknik). Bayumedia Publishing Malang, 17(1993), https://doi.org/10.1007/BF00353157

Aprilia, A. (2017). Analisis Pengaruh Fraud Pentagon terhadap Kecurangan Laporan Keuangan Menggunakan Beneish Model pada Perusahaan Yang Menerapkan Asean Corporate Governance Scorecard. Jurnal ASET (Akuntansi Riset), 9(1), 101. https://doi.org/10.17509/jaset.v9i1.5259

Apriliana, S., \& Agustina, L. (2017). The Analysis of Fraudulent Financial Reporting Determinant through Fraud Pentagon Approach. JDA Jurnal Dinamika Akuntansi, 9(2), 154-165. https://doi.org/10.15294/jda.v9i2.4036

Association of Certified Fraud Examiners. (2016). Report To The Nations On Occupational Fraud And Abuse 2016 Global Fraud Study. Retrieved from fraud yang paling sulit untuk diukur sehingga memungkinkan terjadinya ketidakakuratan dalam mengukur tingkat integritas.

\section{Batasan}

Penelitian ini tidak merepresentasikan persepsi pegawai instansi pemerintah secara merata di setiap daerah karena responden tidak berminat untuk mengisi kuesioner jika harus menyebutkan instansinya. Oleh karena itu, diperlukan kehatihatian dalam menggeneralisasi hasil penelitian ini. Keterbatasan jumlah responden tentunya dapat menurunkan derajat keterwakilan pegawai pemerintah yang bukan responden dalam penelitian ini.

\section{Rekomendasi}

Penelitian selanjutnya diharapkan dapat mengkaji lebih banyak lagi indikator-indikator yang dapat dikembangkan dari variabel-variabel yang terkait dengan fraud berupa penyalahgunaan aset, kecurangan laporan keuangan atau korupsi, seperti tekanan, peluang, rasionalisasi, kapabilitas dan integritas. Selain itu, penelitian selanjutnya disarankan untuk menggunakan metode kualitatif dalam metodologi penelitian atau menggunakan kombinasi metode kualitatif dan kuantitatif. Dengan demikian akan terjadi variasi atau keragaman dan hasilnya lebih meyakinkan.

https://www.acfe.com/rttn2016/docs/2016-report-tothe-nations.pdf

Cohen, J. (1992). Quantitative Methhods in Psychology: A Power Primer.

Didi, D., \& Kusuma, I. C. (2018). Faktor-Faktor yang Berpengaruh terhadap Kecenderungan Kecurangan (Fraud): Persepsi Pegawai Pemerintahan Daerah Kota Bogor. Jurnal Akuntansi Dan Keuangan Indonesia, $15(1), \quad 1-20$. https://doi.org/10.21002/jaki.2018.01

Fadhil, H. (2018, December 10). KPK: Negara Rugi Rp 2,3 T dari e-KTP, tapi Baru Balik Rp 500 M. Detiknews. Retrieved from https://news.detik.com/berita/d4337444/kpk-negara-rugi-rp-23-t-dari-e-ktp-tapibaru-balik-rp-500-m

Faisal, M. (2013). Analisis Fraud di Sektor Pemerintahan Kabupaten Kudus. Accounting Analysis Journal, 2(1). https://doi.org/10.15294/AAJ.V2I1.1181

Faradiza, S. A. (2019). Fraud Pentagon dan Kecurangan Laporan Keuangan. EkBis: Jurnal Ekonomi Dan Bisnis 2(1) 1-22 Retrieved from httn //eiournaluin- 
suka.ac.id/febi/ekbis/article/view/1060/621

Fitri, F., \& Nadirsyah. (2019). Pengaruh Tekanan (Pressure), Kesempatan (Opportunity), Rasionalisasi (Rationalization), dan Kapabilitas (Capability) terhadap Kecurangan Pengadaan Barang/Jasa di Pemerintahan Aceh dengan Pemoderasi Budaya Etis Organisasi. Jurnal Imiah Mahasiswa Ekonomi Akuntansi, 4(3), 412-427. Retrieved from http://jim.unsyiah.ac.id/EKA/article/view/12575\#

Fitriany, E. D. P. (2014). Analisis Pengaruh Integrity dan Corporate Governance terhadap Probbilitas Fraud. Universitas Indonesia. Retrieved from http://lib.ui.ac.id/naskahringkas/2016-05/S56627Erroz Dany Perdana

Institute Internal Auditors. (2016). International Standards for The Professional Practice of Internal Auditing (Standards). Retrieved from www.globaliia.org

Irphani, A. (2017). Pengaruh Tekanan, Keefektifan Sistem Pengendalian Internal, Perilaku Tidak Etis, dan Jabatan Dalam Pengelola Keuangan terhadap Fraud (Studi pada Satuan Kerja Perangkat Daerah Kota Metro). University of Lampung. Retrieved from https://digilib.unila.ac.id/25440/20/tesis tanpa bab pembahasan.pdf

Manossoh, H. (2017). Faktor-Faktor Penyebab Terjadinya Fraud pada Pemerintah di Provinsi Sulawesi Utara. Jurnal EMBA: Jurnal Riset Ekonomi, Manajemen, Bisnis Dan Akuntansi, 4(1). Retrieved from https:/ejournal.unsrat.ac.id/index.php/emba/article/vi ew/11649

Mazkiyani, N., \& Handoyo, S. (2017). Audit Report Lag of Listed Companies in Indonesia Stock Exchange. Jurnal Aplikasi Bisnis, 17(1), 77-95. https://doi.org/10.20885/jabis.vol17.iss1.art5

Mohammad Rezaei, F., \& Mohd-Saleh, N. (2018). Audit Report Lag: The Role Of Auditor Type and Increased Competition in The Audit Market. Accounting \& Finance, 58(3), 885-920. https://doi.org/10.1111/acfi.12237

Muhson, A. (2015). Teknik Analisis Kuantitatif 1 Teknik Analisis Kuantitatif. Retrieved from http://staffnew.uny.ac.id/upload/132232818/pendidik an/Analisis+Kuantitatif.pdf

Mulyadi, M. (2018). Penelitian Kuantitatif dan Kualitatif serta Pemikiran Dasar Menggabungkannya. Jurnal Studi Komunikasi Dan Media, 15(1), 128. https://doi.org/10.31445/jskm.2011.150106

Nisa, K., Oktafiana, N. F., \& Permata Sari, S. (2019). Fraudulent Financial Statement Ditinjau dari Model Fraud Pentagon Horwath. Purworejo. Retrieved from

http://eproceedings.umpwr.ac.id/index.php/urecol9/a rticle/viewFile/865/757

Pristiyanti, I. R. (2012). Persepsi Pegawai Instansi Pemerintah Mengenai Faktor-Faktor yang Mempengaruhi Fraud di Sektor Pemerintahan. Accounting Analysis Journal, 1(1), 1-14. Retrieved from http://journal.unnes.ac.id/sju/index.php/aaj/article/vie w/707

Rastika, I. (2011, November 21). Penjualan Aset PT Barata Indonesia Diketahui Kementerian BUMN. Nasional Kompas. $\quad$ Retrieved from https://nasional.kompas.com/read/2011/11/21/14365 711/Penjualan.Aset.PT.Barata.Indonesia.Diketahui.K ementerian.BUMN

Kountur, Ronny. (2009). Metode Penelitan untuk Penulisan Skripsi dan Tesis. Jakarta : Percetakan Buana Printing.

Saputra, A. (2019, March 17). Skandal Bertubi-tubi di Kemenag, Kasir pun Bisa Korupsi Rp 3,3 Miliar! Detiknews. Retrieved from https://news.detik.com/berita/d-4471169/skandalbertubi-tubi-di-kemenag-kasir-pun-bisa-korupsi-rp33-miliar

Sarpta, R. B. (2018). Analisis Fraud Pentagon dalam Mendeteksi Fraudulent Financial Reporting Menggunakan Beneish M-Score Model (Studi Empiris pada Perusahaan Manufaktur yang Terdaftar di Bursa Efek Indonesia Tahun 20142016). Universitas Bandar Lampung. Retrieved from http://digilib.unila.ac.id/31452/3/Skripsi Tanpa Bab Pembahasan.pdf

Sasongko, N., \& Wijayantika, S. F. (2019). Faktor Resiko Fraud Terhadap Pelaksanaan Fraudulent Financial Reporting ( Berdasarkan Pendekatan Crown's Fraud Pentagon Theory ), 4(1), 71-81. Jurnal Riset Akuntansi dan Keuangan Indonesia

Siahaan, M., Umar, H., \& Br, R. (2019). Fraud Star Drives to Asset Misappropriation Moderated by Internal Controls 欺 诈 之星 驱动资产 内部控制 导 致的盗用. Journal of Southwest Jiaotong University, 54(4), 1-10.

Sugiyono. (2017). Metode Penelitian Kuantitatif, Kualitatif, dan R\&D. Bandung : Alfabeta,CV.

Transparency International. (2018). Corruption Perceptions Index 2018: Global Scores.

Umar, Haryono. (2016). Corruption The Devil. Jakarta : Penerbit Universitas Trisakti.

Wicaksana, E. A., Suryandari, D., \& Semarang, U. N. (2019). Pendeteksian kecurangan laporan keuangan pada perusahaan pertambangan di bursa efek indonesia, 4(1), 44-59.

Yudistira, G. I. N. A. R., Sujana, E., \& Yuniarta, A. G. (2017). Pengaruh Aspek Tekanan, Penegakan Peraturan, Rasioanlisasi, dan Wewenang Pegawai terhadap Fraud (Studi Empiris Pada Skpd Kabupaten Karangasem). E-Journal S1 Ak Universitas Pendidikan Ganesha, 8(2).

Zulkarnain, R. M. (2013). Analisis Faktor yang Mempengaruhi Terjadinya Fraud pada Dinas Kota Surakarta. Accounting Analysis Journal, 2(2), 126-131. Retrieved from https://journal.unnes.ac.id/sju/index.php/aaj/article/vi ew/2852/2643 